\title{
Exposure as Collected Occurrence
}

National Cancer Institute

\section{Source}

National Cancer Institute. Exposure as Collected Occurrence. NCI Thesaurus. Code C117478.

An indication or description of a collected exposure occurrence. 